\title{
Ronggeng Dukuh Paruk Trilogy by Ahmad Tohari: Understanding of Cultural Geography and Identity
}

\author{
Surherni Surherni* ${ }^{*}$ Gusti Adriana Yarlis Yarlis \\ Fakultas Seni Pertunjukan, Institut Seni Indonesia Padangpanjang, Bahder Johan, \\ Padangpanjang, 27128, Indonesia
}

\begin{abstract}
This article intended to reveal cultural variance from Trilogi Ronggeng Dukuh Paruk by Ahmad Tohari. The existence of Srintil as ronggeng showed peculiarity that can not be found in another areas. This identity showed in ceremonial stages such as bathing procession of ronggeng candidate at Kisecamanggala cemetery before officially as Ronggeng. This ritual start with one round of Ronggeng Dance by Srintil without vulgar wawl and errotic moves. Srintil paraded to the Kisecamanggala cemetery to do the ritual. Next step is, drape opening ceremony as if a competition to fight over the virginity of Ronggeng candidate. Before undergo the ceremony, Srintil must be preconcerted to have an Indang. When Srintil just enter the world of Ronggeng, it is believed that Ronggeng is more respected than stay at home woman. After uncovered that Ronggeng is full of lust, Srintil got neglected especially after 1965 incident. In the end, both Srintil and The Dukuh Paruk wrecked without any second chance to show their pride in the slightest. She was crashed in the middle of ruined Dukuh Paruh grassland. The research used documentation methode for the collecting datas research and inductive analytics as analyzing data methode. Dokumentation analysis is collecting data methode where texs and messages in a document will classified into a relevant coding with research.
\end{abstract}

Keywords: Ronggeng Dukuh Paruk, cultural geography, identity

DOI: $10.7176 / \mathrm{ADS} / 95-03$

Publication date:September $30^{\text {th }} 2021$

\section{Introduction}

The Ronggeng Dukuh Paruk trilogy, consisting of Ronggeng Dukuh Paruk (1982), Lintang Kemukus Dini Hari (1985) and Jantera Bianglala (1986) written by Ahmad Tohari, are local Javanese colored works such as Gandrung, Tayub, Gambyong, Joged, Teledek and Ketik Tilu. The Ronggeng Dukuh Paruk trilogy focuses on a more specific Javanese locale. This novel does not address the Javanese subcultural tradition in general, but instead one of the variants of the Javanese subcultural tradition, namely the Banyumas variant. This element shows the distinctiveness of Ahmad Tohari's local Javanese color

There are a number of local color specifically indicated in the space limited interaction with the system of limited value. As an interaction space that has been designed in such a way that it involves a pattern of relationship between man and man or people with physical environment. The interaction pattern that has been designed is called setting. Setting is an interaction space where someone can develop a relationship face to face in the environment.

(Edeliya and Haryo, 2019) pointed out that every group or community has a unique habit or way of life; as an identity that they are trying to preserve their existence, which means the group lives in a veil with the term communion (Anderson, 2006). What is meant by the imaginary community is how these communities live in a society that they built themselves based on what has been a mutual agreement with similar the mindset or image. Although imaginary community context can be seen as an agent of enriching of human life, but the idea of a unified nation composed of various communities plural society.

Imaginary communities have cultural roots in the form of "perasaan senasib sepenanggungan" (in the same boat feeling) with a deeply held value collectively and attention to the order of the cultures that exist in a particular community (Anderson, 2006). Furthermore Anderson argued that the imaginary community has political roots in identity formation based on self-determination. The imaginary identity often collide with an overarching cultural identity where identity geopolitics imaginary boundaries are.

What about the cultural system of the imaginary community? There are two cultural systems that underlie imaginary communities, namely belief and character (Anderson, 2006). Faith refers to a religion, ideology and/or other belief system that is voluntarily adopted by members of a community. Adherence to this belief system is a unifying factor for the community (Anderson, 2006). Character refers to how a figure in the community acts as a leader and role model for members of the community (Anderson, 2006). In the Middle Ages the figures were usually kings and other nobility but in the modern era it is dominated by politicians due to the belief system described above.

As an imaginary community in the post-independence era of Indonesia, the residents of Dukuh Paruk have their own aspects that make them considered to have habits or ways of life that are different from residents outside Dukuh Paruk. (Anderson 2006) In the concept of an imaginary community that each community has 
different characteristics of living habits, it is not based on the way of life that is considered right or wrong by the dominant group which has more agency. What is more important is how Dukuh Paruk cults Kisecamenggala; a criminal who eventually became a role model in their community. The belief system of the people of Dukuh Paruk is influenced by the teachings of Kisecamenggala about art and Ronggeng's spirituality.

This article aims to analyze the Ronggeng Dukuh Paruk Trilogy using a cultural geography approach and an understanding of identity and representation within the scope of Cultural Studies. The background of "Ronggeng Dukuh Paruk" is told as a remote and unpretentious hamlet. Twenty-three houses are inhabited by descendants. It is said that the ancestor of all the people of Dukuh Paruk was Kisecamenggala, a bromocorah who deliberately sought the quietest area as a place to spend his bravado. In Dukuh Paruk, Ki Sicamenggala finally left his flesh and blood. All residents of Dukuh Paruk are aware of Ki Secamenggala's past, who was a parasitic figure in society, but still adore him. The next one creates a special mystical Qibla flow for Kisecamenggala spirit worshipers. Even though the Ronggeng tradition, which is considered immoral by people outside Dukuh Paruk, can actually give encouragement and a good image to Dukuh Paruk, especially Kisecamenggala has given an order to preserve Ronggeng. The discussion will focus on how the setting or place affects the identity and representation of the humans in it and provides meaning in the socio-cultural relations between humans who inhabit the place.

Setting, characterization and storyline cannot be separated from each other, these are the facts that make up a literary work. Ronggeng Dukuh Paruk's novel is the first part of the trilogy. This novel is interesting to study because it tells the journey of a person who will hold a title, Srintil who has received the spirit of Kisemenggala, must first undergo various sacred ceremonies. This ceremony includes the bathing of the prospective ronggeng in front of the Kisecamenggala grave and the bukak kelambu ceremony can be called a kind of competition to fight over the virginity of prospective ronggeng.

Even though she was contested by Kartareja (a ronggeng shaman) but unexpectedly, Srintil handed over her virginity to Rasus. Actually, Ronggeng's status was very disappointing for Rasus because he wanted the figure of a mother he was looking for to have disappeared. Then he was forced to give up Srintil for Dukuh Paruk so he was determined to leave Dukuh Paruk.

Although it is not explicitly stated where this story takes place, except for the name of Dukuh Paruk, the geographical setting of the story is factually in the Banyumas area. In Java, there are many ronggeng such as Cirebon, Bojonegoro and Banyumas, each of which has its own characteristics. However, the tradition of bukak kelambu to fight over the virginity of the candidate for ronggeng is a prerequisite that is only taken in the Banyumas area.

Indeed, there is no direct indication that the existence of ronggeng is for fertility ceremonies. However, the bukak kelambu ceremony directly involves a woman who will be crowned a ronggeng first having to have sex. The process of sexual intercourse as experienced by the character Srintil in the novel Ronggeng Dukuh Paruk during bukak kelambu ceremony is not just an outlet for biological desires, but rather as an actualization of fertility statements related to the preservation of human life (Budiarti, 2003, p. 89).

The problem of ronggeng that was worked on by the author seemed to originate from the geographical setting (place) that was presented. Furthermore, this novel tells about the traditions of the Dukuh Paruk community with a magical ceremony associated with the spirit of Kisemenggala. The tomb is considered the mecca of their spirituality. Sacredness has a big influence on everyday life so that whatever happens there is always associated with the sacredness of the Kisemenggala tomb. This fact also causes belief in mysticism and incantations to thrive.

\section{Research Methods}

Document analysis method as data collection method and inductive analysis as data analysis method. Document analysis is a data collection method where the text and messages in a document will be classified into coding categories that are relevant to the research theme (Bryman, 2012). The document in this research is the novel Ronggeng Dukuh Paruk with the first category coding in the form of Dukuh Paruk as an imaginary community and the conceptual basis for Dukuh Paruk as a community, especially how a belief system and character can unite them (Anderson, 2006). The second category is Kisemenggala as a charismatic figure in Dukuh Paruk and his ability to spread influence through his charisma and synergize with Dukuh Paruk as a geopolitical environment

The third category is the Dukuh Paruk Community as a cult social system and how Kisemenggala beheading and the Dukuh Paruk residents fill their roles in running the system. Then by using inductive analysis (Bryman, 2012), an idea that is specific to general will be created in each discussion. All the results of the discussion will be evaluated to produce conclusions at the end of the article. 


\section{Results And Discussion}

3.1 Cultural Geography, Representation and Identity

Cultural geography is concerned with understanding the interrelationships between people and places, and is not simply an attempt to put cultural locations in their proper place. Based on the understanding that all forms of culture are syncretic in the sense that they are always a mixture of more than one kind of culture or hybrid, intercultural connectedness becomes increasingly prominent. The consequence is that studying geography and this relationship becomes something significant. It should be remembered that connectedness is cross-border and transcends all forms of cultural and geographic restrictions, intertwined and becomes one of the determining factors that shape people's lives (Baldwin et al., 2008, p. 179)

Furthermore, Bayu Kristianto (Kristianto, 2009, p. 111) in Middleton, explains that identity is formed by connotations that arise when humans live in a certain place or location. Thus, cultural geography discusses how space and place are shaped by - and - shape - the beliefs and values held by the people who inhabit a particular place, which in itself shapes the identity of the community. So the analysis carried out in cultural geography is concentrated on how time and space factors affect culture through the social practices that occur in it. Social action that takes a certain time and place becomes something important.

Cultural geography can be understood as a place, a place is not something that is independent or separate from humans. Instead, the place is created as a product of certain social conditions that create the place (Giles and Middleton, 1999, p. 105). Furthermore, Giles and Middleton argue that place is always full of meaning, and because of the fulfillment of this meaning, cultural geography emphasizes the understanding that the relationship between place and these meanings should not be ignored. Place must always be taken into account in any cultural analysis. (Giles and Middleton 1999:125).

Representation shapes the individual and creates the collective identity of a society because it is in this representation that meaning is created. Thus, who we are individually and as a group is more determined by external factors, because representations are shaped by cultural processes and symbolic systems in such a way that our identity is formed and our position as a subject becomes clear. With the representation system, the creation of meaning and the formation of identity become increasingly intertwined because it is in the representation system that this connection occurs.

The identity of something that is produced in discourse, and discourse itself is shaped by a number of rules and conventions that shape it, and according to Michel Foucault, discourse is what defines and creates objects of knowledge. (Barker, 2000:20) Identity is something that is artificial; something formed by representations and not something formed naturally. The main factor forming identity is language.

Jacques Lacan, humans are the subject of the structural process of language because it is in and through language that humans become subjects (Storey 2007:77-78). Therefore, subject and subjectivity only exist and are shaped by language, identity, which is based on subjectivity, never stands alone. Identity depends and is formed by external factors, such as language as an external symbolic order which humans enter into to find their subjectivity and become members of society.

\subsection{Identity, Representation and Meaning in Ronggeng Dukuh Paruk}

The social setting of this novel can be seen from the daily life of the people there who are impoverished due to the ignorance and laziness of its inhabitants. They are satisfied with being agricultural laborers and small-scale cassava cultivation. At harvest, liquor enters every door of their house. Calung sounds, ronggeng songs and obscene jokes lulled them to sleep. Identity and norms that consider normal acts of sexual freedom and prostitution are actually based on economic motives; Due to poverty, which is a common sight in Dukuh Paruk, it provides an agency for residents to understand actions that are considered contemptible for residents outside Dukuh Paruk. 


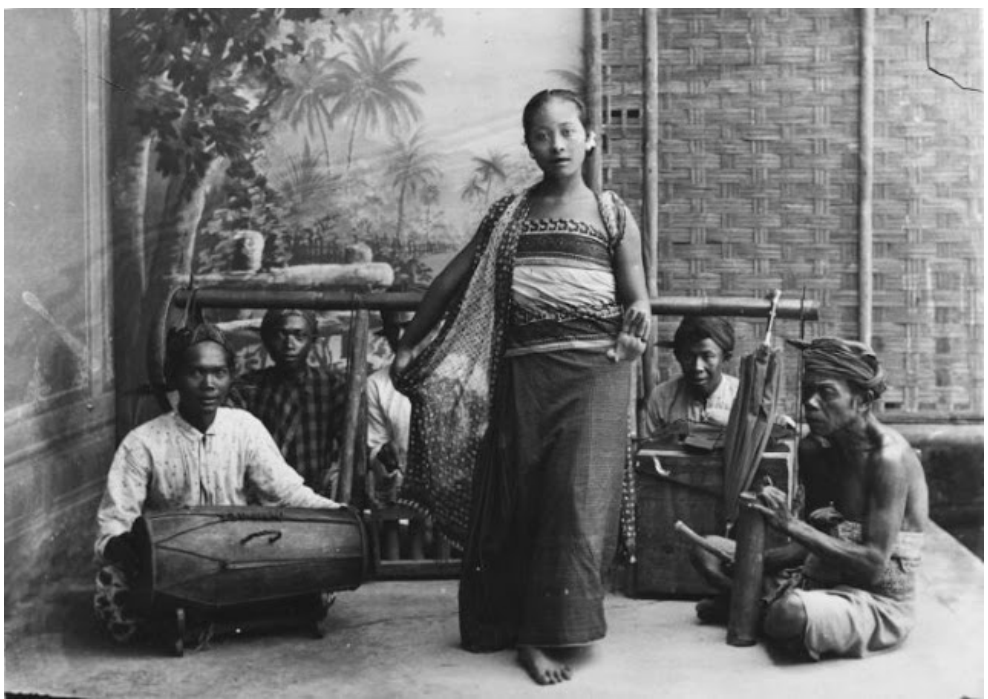

Figure 1. Ronggeng's portrait of the 1990s

https://www.wijatnikaika.id/2011/07/ronggeng-dukuh-paruk-dan-komoditisasi.html downloaded tgl 04-08-2021

Social background with local meaning can be seen through the existence of Srintil. Her existence as a ronggeng makes her a collective property of the Paruk community so that Srintil has the highest social status in society. The relationship between the problems of this novel and the local setting is further clarified through the author's perspective in solving the problems presented in a way that is typical for the people of Dukuh Paruk.

This can be traced from the conflicts between Rasus as the main character and Srintil. From the start, Rasus did not like Srintil to be ronggeng because in that woman he found the image of his mother. Rasus doesn't want his mother's image to manifest in a woman Ronggeng, then he realizes that Srintil is not a private property but a collectivity of Dukuh Paruk residents.

Solving the problem of the author's attitude is realized through Rasus's more inward-oriented attitude, which is concerned with the survival of ronggeng. That's why when Rasus returned to Dukuh Paruk to fight the robbers together with Sergeant Slamet he refused Srintil's offer as a ronggeng, it would be the same as ending Srintil's history.

As an imaginary community in the post-independence era of Indonesia, Dukuh Paruk residents have their own aspects that make them considered to have different habits or ways of life from residents outside Dukuh Paruk (Anderson 2006). Anderson further points out that in the concept of an imaginary community, that society does have characteristics of different habits of life; not based on the way of life that is considered right or wrong by the dominant group who has more agency. What is more important is how the people of Dukuh Paruk cult of Kisecamenggala; a criminal who eventually became a role model in their community. The belief system of Dukuh Paruk is influenced by the teachings of Kisecamenggal around art and Ronggeng's spirituality. It seems that Kisecamenggala is a charismatic figure in Dukuh Paruk

It is said that people who are familiar with the mystical world, including the incantation of mercy, also cannot be separated from the role of pimps like Kartotejo's grandmother who controls these mystics. This fact makes Rongeng Dukuh Paruk's local setting unique and rarely found in other novels. Kartorejo as a bridge as well as a pimp from Srintil; he was the one who bred Srintil to become a charming Ronggeng dancer, kenes, and opened up opportunities for certain men who wanted to sleep with her in order to gain multiple benefits apart from performing the Ronggeng dance.

As a form of cultural activity for the Banyumas people, ronggeng serves to fulfill the instinctive needs of the supporting community for beauty. It is said that the performing arts are held in addition to be used as a fulfillment of ceremonies also become part of the spectacle to entertain the public. It is understandable that a dance that appears on the stage is not just a form of movement arrangement and technical skill or virtuosity of the dancers, but requires a deepening of content, and all of that must reach the target or "communicative meaning" to the audience. (Hadi 2012:9). Dance as text with all the events in it is something that can be read and interpreted freely just like reading a text. (Putra 1998: 20). Free interpretation of the text must still use the concept or reference source that can be trusted and can give the right interpretation. Therefore, the required interpretation to reveal the meaning hidden behind the meaning is directly visible. (Surheni 2015:64). 


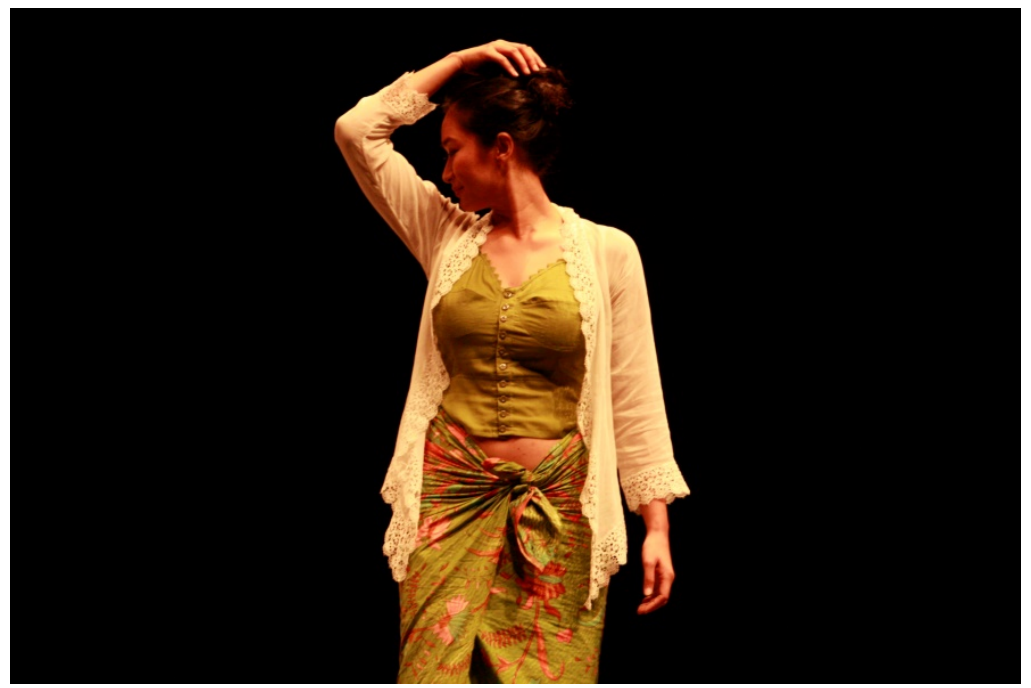

Figure 2. Ronggeng Dancer

Source : https://persinggahan.files.wordpress.com/2009/12/wap20091222-15.jpg

downloaded tgl 04-08-2021

Witnessing the young ronggeng sway swing with a beautiful face indeed a refreshing way for farmers in rural areas who tend to be poor Banyumas entertainment facilities. Until now though is getting a lot of entertainment facilities and penetrated to the villages, every show ronggeng always filled with spectators. The arrival of the ronggeng are always welcome hysterical screams and kesengsem whistles spectators who witnessed the appearance of the dancer adored.

As a means of entertainment, ronggeng quite qualify. Dancers is a young woman (teenager) with an attractive face (beautiful). Beauty is a key prerequisite for someone who wants the profession as dancers. However, she must master the dance well and with the provision of voice (vocal) is also good. She than as a dancer also as a vocalist in the arena staging. Without a good quality of dance and sound undoubtedly presence on stage will be less vibrant and inviting not appeal to the audience.

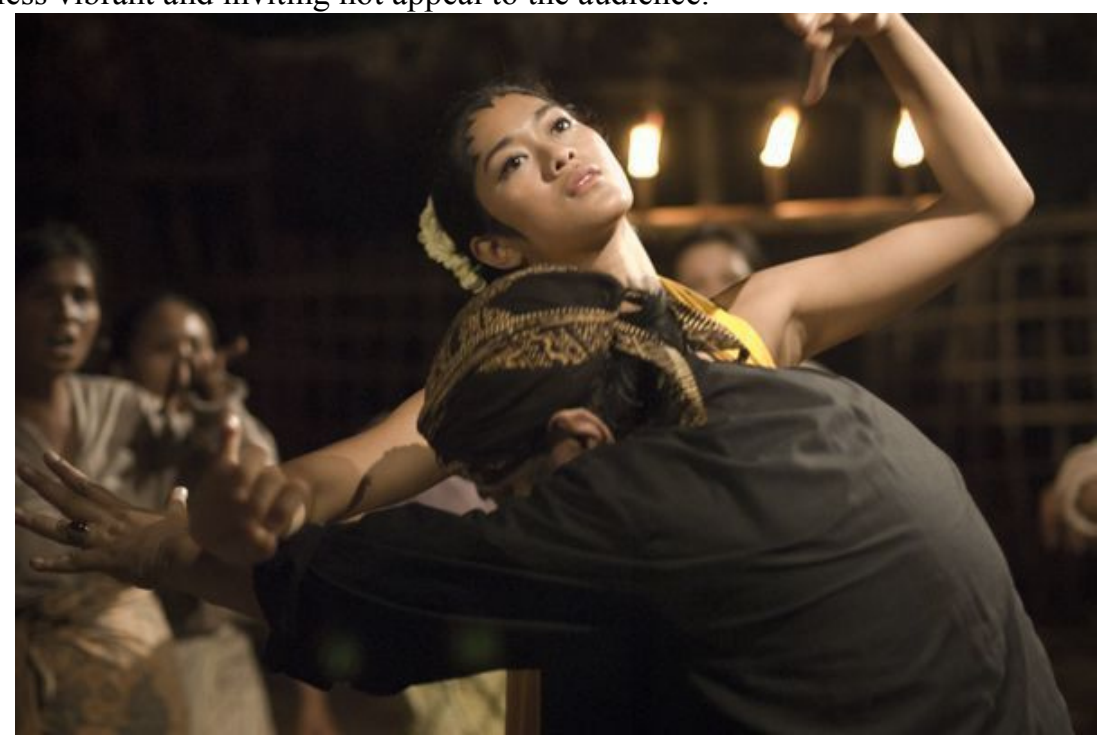

Figure 3. Ronggeng's Performance

Source : https://cinemapoetica.com/sang-penari-ulasan-atasnya-dan-ulasan-atas-dua-ulasan-tentangnya/ downloaded tgl 04-08-2021

"The charm of women continues to be a central and a magnet that makes dance liked and even loved by the audience. Women who engage in world dance performances in particular should be able to survive in the shooting and negative charges. It is not a strange thing if women who are involved in the world of performing arts, including Sundanese people, have a "poor" brand image. This is a remnant of history that carved out the negative excesses of ronggeng in the past. Society corners ronggeng with lowly dancers who always exploit the body to bring out its attractiveness with erotic movements surrounded by men, changing partners, having pellets, good at seducing people to destroying people's households." (Caturwati, 2009, p. 117).

It seems that this performing art is really used as a means of self-entertainment, especially for the people of 
Banyumas. At the time of performing arts the audience can participate in dancing with ronggeng. Thus, Soedarsono's statement is true, namely that folk dance is a dance that emphasizes joint participation rather than artistic arrangement aimed at the audience. This show in the past really opened up opportunities for the audience to dance together with the dancers on stage. (Soedarsono 1978:1)

This show is actually not only entertainment that can be obtained by the audience. In it there are philosophical teachings that are useful for individual and social life. For the people of Banyumas, what is considered kasampurnaning urip (the perfection of life) is knowing about sangkan paraning urip (origin and purpose of life). Without knowing sangkan paraning urip, man will certainly not know who they are, where they come from, and where they are going after living in this mortal world. The axis of life's purpose is union with God.

An understanding of the nature of life is expressed through the Eling-eling gending. Which means that humans in living life in the world must always remember those who live, remember sangkan paran (origin and destination). This is the most important philosophy for Javanese people, including Banyumas people. Human existence in the world does not exist by itself. It exists because it was held. Live to be lived. Eventually he returned to the substance of the Almighty who has held and support him, namely God..

The teachings of life and life are conveyed symbolically. To find out requires a deep understanding of the meaning of the whole performance. Many of the poems or sinden are full of meaning. In the context of social life, there are hidden teachings through gending poems as well. The teachings of harmony in life can be seen in the poem gending bunga glepang which essentially contains a love song that is full of meaning about the teachings of goodness for humans in social life. Breakup is not the end of everything, because there are still a lot of time to regain the love with others. Second, the brotherhood must always help each other to the best of their ability. Third in social life don't do all manner of fun because the resulting exposed to fines and dealing with the law.

Various teachings of goodness are not conveyed verbally but are encoded, personified, and metaphorized in certain ways or in Javanese they are often called medhang miring and nyampar pikoleh. Medhang miring means that in delivering the teachings it is really encoded so that it cannot be directly known through the words or expressions contained in the poem. As for nyamper pikoleh, it means that the teaching is conveyed through words or expressions with multiple meanings which, when interpreted verbally, are different from the intended symbolic meaning.

View towards ronggeng be pros and cons for society supporters. Such conditions cannot be separated from one of the functions of ronggeng as an entertainment medium. The remnants of the past tradition of ronggeng are always associated with covert prostitution. Procession bukak kelambu such as described in the novel Ronggeng Dukuh Paruk widely being used to impingement sexual appetite. This fact becomes a trade mark for ronggeng as if it is synonymous with covert practice.

Negative views on ronggeng mainly come from the santri. Santri are adherents of Islam who hold strongly to Islamic doctrine, especially in terms of moral and social interpretation. (Geertz 1983:173). According to this view (Abangan, santri and priyayi in Javanese society), watching ronggeng and the like is a permissible act or can even be classified as an unlawful act. When viewed from the situation that occurred in the past, this view is not entirely wrong, because in fact through the ronggeng performances there are practices that are contrary to Islamic doctrine. However, when viewed from the element of art, then there is nothing that should be rejected by the teachings of the Prophet.

\subsection{Local Background Lintang Kemukus Dini Hari}

The problems dealt with in this novel are like the novel Ronggeng Dukuh Paruk. In the ronggeng Dukuh Paruk, the story centers on the characters Srintil and Rasus, but in Lintang Kemukus Dini Hari, Srintil is the main character. Since Rasus refused her offer to become her husband, Srintil was deeply disappointed. Srintil is not aware of the prevailing nature in her village that ronggeng is not allowed to love men. The departure Rasus make Srintil soul is torn then She nrimo (accept) the fact (Sahid, 1986, p. 2).

Nur Sahid further explained that Srintil's disappointment with Rasus was vented to a baby named Goder, a child of Tampi's neighbour, through Goder her maternal instincts were felt to be channeled. It was precisely by breastfeeding Goder that she felt true sexual satisfaction.

One aspect of the local setting of Lintang Kemukus Dini Hari can be seen from Srintil's attitude to life, which is typical of Javanese women, resigned and nrimo. In addition, the local setting is also marked by the gowokan tradition that Srintil did with Waras. At first, Srintil was hesitant to do so because she had never been a Gowok even though he had actually served many men. Gowokan is a traditional sex education tradition aimed at young people who are ready to enter marriage. The gowokan tradition is one of the customs that once prevailed in the geographical area. This story is clear that the gowokan tradition in Lintang Kemukus Dini Hari plays a role in reinforcing local colors because this tradition has indeed been a tradition in Banyumas.

Belief in the mystical and sacred tomb of Kisecamenggala also emphasizes the local setting. During his lifetime, Kisecamenggala ordered Ronggeng to be a part of Dukuh Paruk's life. That is why ronggeng art always 
has a social and spiritual meaning because it contains magical values rooted in the sacredness of the Kisecamenggala tomb.

The characters' familiarity with their ancestors, spells and amulets shows that apart from being familiar with the empirical realm, the meta-empirical realms of the two elements are intermingled with each other and the empirical realm has always been infused with the supernatural. Other elements that complement the local setting can be seen through the familiarity of subordinate figures with a shaman who has black magic, namely Tarim. Marsuasi tried to take revenge against Srintil but for fear of bad consequences he did not kill Srintil and only embarrassed him in public.

The social background can be seen from the unrest of the people of Dukuh Paruk before the outbreak of the G 30 S PKI rebellion in 1965. In that year Srintil, dignified, beautiful, and still young, had to deal with historical provisions that had never been imagined forever. She and the people of Paruk, who did not know the meaning and purpose of any politics, were forced to accept the sap due to being manipulated by a group that adheres to communist ideology, namely the Bakar group. When the rebellion was thwarted those involved and their sympathizers were arrested. Inevitably Srintil and his entourage were arrested.

In contrast to the ronggeng Dukuh Paruk in this novel, the social setting with local meanings is less emphasized. It can be understood that as a work in the form of a trilogy, although each novel shows its integrity to become a stand-alone story, it does not rule out the connection between the three novels' storylines.

\subsection{Local Background Jantera Bianglala}

As well as can be seen in two parts of the trilogy above, " Jantera Bianglala " This also shows similarities geographic background and the problem as shown author. Background georafis still Dukuh Paruk while problems remain regarding ronggeng tilled. Local background story is punctuated by Srintil life attitude that "a note of resignation" in the face of ridicule people because she was a former political prisoner who served time in prison for two years. As a former political prisoner she felt did not have more dignity in front of the public. Meanwhile, the community itself seemed unable to accept her presence. Srintil's inner experience is essentially the same as that experienced by Karman, the protagonist of The Dome by Ahmad Tohari's Dome. Srintil was able to find his self-worth when Bayus, an irrigation project leader from Jakarta, start to offer the hope of love Srintil though in the end it was just an empty dream because Bayus impotent.

Social background Jantera Biang Lala marked by a shift in values in Dukuh Paruk. This situation is reflected in Srintil's actions in trying to leave Ronggeng's world and turn into a housewife. Along with this desire, Rasus, who is currently on duty in Kalimantan, is aware that he is apathetic towards the life of Dukuh Paruk. Rasus is a person who is aware of his existence and responsibilities as a resident of Dukuh Paruk.

Shifting values of a society which is one element of the social background of this novel seem obvious after the death Sukarya, a kamitua who became a role model. Life experiences during the political upheaval in 1965 have changed the perspective of Dukuh Paruk. A person who becomes a role model is no longer a person who is spiritually close to the spirit of Kisecamenggala as Sekarya, but Rasus who is identical with the ruler so that it is easier to deal with. One of the consequences of the shift in values in the Dukuh Paruk community is that the sacred authority of the Kisecamenggala tomb is gradually fading away.

In addition to the above elements of the social background Jantera Ferris also characterized by social changes that occurred in Paruk. Construction of irrigation projects with a variety of modern technologies by the people of Jakarta, French, Japanese lifestyle brought urbanity has an effect on people's lives Paruk.

Clear that the influx of construction and modernization to Paruk environment has given rise to social change in the community life of the area. Social background which refers to the scope of sub-culture looks at changes in the way of life Srintil. At first he was proud of his status as a ronggeng then vice versa. It is interesting to observe how the place plays a major role in shaping the identity of Srintil. Dukuh Paruk is not a place without meaning, in fact Dukuh Paruk is a system of representation.

After local color Ronggeng Trilogy Java Dukuh Paruk described above is now becoming more apparent that the novel shows the peculiarities that are not owned by another novel. Aspects that show this peculiarity include the ronggeng cycle, marital sex, outlook on life, mysticism and an attitude of dependence on the natural surroundings.

The existence of Srintil as a ronggeng shows a uniqueness that cannot be found in ronggeng in other areas. The uniqueness appears in the stages he goes through as a prospective ronggeng such as the bathing ceremony at the Kisemenggala tomb and the Bukak kelambu ceremony. Before undergoing these two ceremonies, Srintil must first confirm that she has an indang. The specific actions are the sex and marital life in this discussed novel.

When entering new world ronggeng, she believed that ronggeng was more respectable than somahan women. After the ronggeng world was proven full of actuation lust, did not lead to harmony of life, drove her to a holding cell for two years and, more importantly led to the departure Rasus. Finally, Srintil was more convinced of the beauty of a woman who is called a housewife. 
Past and Present

- Ronggeng,

- Dower,

- Sulam,

- Gundik,

- Goder, (vent),

- $\quad$ political prisoner, is incompatible with the highest purpose of life.

- Dream world

- Somahan women

- Rasus

- Housewife

- Child

- Dignified

- Ambassador of the conscience of life in accordance with the highest purpose of life.

The two statuses of women are always in opposition in Srintil's life without being able to let go of one of them, for her ronggeng is reality while somahan women are still imaginary. Then, as can be seen in the local description above, Srintil's view of life that stands out is resignation and nrimo. This view of life clearly marks the distinctiveness of local Javanese colors. On the other hand, Rasus does not give up and nrimo in his life. After leaving Dukuh Paruk he became a tobang for Sergeant Slamet. The success quell robberies in Dukuh Paruk gave him the opportunity to become a soldier. These life changes may not occur if he was just nrimo. In many ways, Rasus is always in opposition to Srintil. The controversy includes views on life, insights, professions, and attitudes of religiosity. Rasus does not give up easily, orientation, army, Islamic religion, dynamic, agent of change, while Srintil is resigned, nrimo, Dukuh Paruk, ronggeng, belief system, static. The opposition of Rasus and Srintil shows that Rasus is identical to modern humans while Srintil is traditional.

The mystical element that has been mentioned in the study of the local setting aspect also strengthens the local color of Tohari's novel. Emergence of mystical elements become an integral part of the belief system of the majority of people of Java. How a belief system and character can unite them. The tendency of the Javanese to be ethical and obedient to the customs inherited from their ancestors is reflected in the people of Dukuh Paruk who consider the Kisemenggala tomb as the mecca of spirituality. Kisecamenggala as a charismatic figure in Dukuh Paruk and how he was able to spread his influence through his charisma through social conditions that synergize with Dukuh Paruk as a geopolitical environment.(Adair-Toteff, 2005).

Its sacredness affects daily life so that whatever happens there is always associated with the Kisecamenggala tomb. This led to the belief in incantations, amulets and the love of fertile life, even Ronggeng was considered to contain magical values originating from the sacredness of the Kisecamenggala tomb.

Dukuh Paruk can be said to be a community group whose lives still depend on the surrounding natural conditions, the daily needs of eating (iles-iles, cassava), drinking, bathing and so on can be fulfilled by the generosity of nature, for example, shampooing simply using straw ash. If someone is poisoned, it can be cured by burying the victim's body up to the neck so that the sweat is absorbed by the soil and many other examples. All are supported by Kisecamenggala's last message which says that harmony with nature is more reassuring to the soul than all violence (Jantera Biang Lala). Natural phenomena, no matter how small, cannot stand alone apart from the will of the universe. The behavior of certain birds and animals can give a signal to the people of Dukuh Paruk about something that will happen in the future.

"As far as foreign animals that approach, let alone enter the house, anyone in Dukuh Paruk will read it as a bad omen. And this morning while sitting petrified in the front room, Sukarya's back was hit by something cold and soft, a lizard. The two creatures were both shocked. The beast fled after dropping to the ground and then crept rapidly against the wall. Sukarya was no less fast, with rags to clean the table, he whipped the lizard, he rubbed it with his feet, " asu bunting you dead" (Lintang Kemukus Dini Hari, 79) (Tohari, 2011, p. 79).. The hunch or sapphire started when a bird was found dead after it flew into Sukarya's house and hit the glass cupboard. Finally, it was proven that these incidents were related to the disaster that befell Dukuh Paruk in the future, namely the entry of the Bakar Communist Party group, causing Srintil to be imprisoned for two years and Dukuh Paruk being burned to the ground.

Way of life and attitudes that are still dependent on natural conditions and environment of their own show including traditional society. This marks one of the local colors of the Ronggeng Dukuh Paruk Trilogy. A number of the above description gives an understanding that behind the beauty of nature paintings of flora and fauna found in the Trilogy Ronggeng Dukuh Paruk it Tohari managed to lift problems rooted in Javanese culture Banyumasan variants. 


\section{Conclusion}

Banyumasan conditions not only appears as a geographic background, but also able to look up local specialties of the local culture. The peculiarity lies in the procedures for welcoming the birth of a new ronggeng, a resigned view of life, and nrimo the appearance of some Javanese vocabulary and Banyumas dialects, sex, local marriages, belief in mysticism, and human dependence on the natural surroundings.

Therefore, the problem of Dukuh Paruk Ronggeng Trilogy relates to the local color stories, resulting in the local color is integrated with the plot. The storyline here moving from conflicts related to the problems presented. It makes the story Ronggeng Dukuh Paruk Trilogy is only possible in an environment of Java, particularly variants Banyumas culture without being able to be moved elsewhere as the same story.

\section{References}

Adair-Toteff, C. (2005) 'Max Weber's charisma', Journal of Classical Sociology, 5(2), pp. 189-204.

Anderson, B. (2006) Imagined Communities. London and New York City: Verso.

Baldwin, E. et al. (2008) Introducing Cultural Studies. 2nd Editio. London and New York City: Routledge.

Bryman, A. (2012) Social Research Methods 4th Ed. Oxford: Oxford University Press.

Budiarti, M. (2003) 'Lengger Antara Mitos Kesuburan dan Hiburan dalam Ekspresi', Jurnal Lembaga Penelitian Institut Seni Indonesia Yogyakarta, 9(3).

Caturwati, E. (2009) Pesona Perempuan dalam sastra \& seni pertunjukan. Bandung: Sunan Ambu STSI Press.

Edeliya, R. and Haryo, P. (2019) 'Representasi Entitas Keilahian Pada Figur Kisecamenggala Dalam Novel Ronggeng Dukuh Paruk Karya Ahmad Tohari', in Kebertuhanan Dalam Kebudayaan Nusantara Brobudur Writers and Cultural Festival dengan Tema Tuhan dan Alam 2019. Magelang.

Giles, J. and Middleton, T. (1999) Studying culture: a practical introduction. Wiley-Blackwell.

Kristianto, B. (2009) 'Film Mendadak dangdut (2006): Pemahaman geografi budaya dan identitas', Wacana, 11(1), pp. 107-128. Available at: http://wacana.ui.ac.id/index.php/wjhi/issue/view/10.

Sahid, N. (1986) Prologue. Yogyakarta: Kelompok Studi Sastra IKIP Yogyakarta.

Tohari, A. (2011) Trilogi Ronggeng Dukuh Paruk. Jakarta: Gramedia Pustaka Utama. 